\title{
THE PRESENT STATUS AND REAL MEANING OF GENERAL SCIENCE.
}

\author{
By Fred. D. BARBER, \\ Illinois State Normal University.
}

One characteristic marks off the nineteenth century from all preceding centuries in the world's history. That characteristic. is the achievements of science and man's mastery over the forces of nature. The nineteenth century opened with such means of transportation and communication only as were enjoyed by Abraham when he journeyed out of Ur of the Chaldees unto the land of Caanan. Under such conditions man, perforce, through all the centuries of his existence had led an isolated life. Within one century, through the influence of the railroad and trolley- line, the telegraph and telephone, the ocean cable and the ocean grayhound, the wireless and the newspaper, time and space were all but eliminated and the whole civilized world became a single social unit.

A second phase of the achievements of science was the recasting of all the activities of daily life. The achievements of science during the last century completely revolutionized the home, the school and its surroundings, every phase of country, town and city life, all methods of heating and lighting, ventilation and sanitation, of obtaining food and clothing, in fact they revolutionized all activities of daily life. To fit into this modern world anywhere, understandingly, some knowledge of the living world and the physical forces about us is a necessity. The social significance of science in modern life gives it ever increasing importance as a subject in our public school curriculum.

Again, the content of our knowledge concerning the natural world and physical forces is increasing with a rapidity and a certainty almost beyond the comprehension of the human mind. For convenience, the mature scientist, viewing this new world of knowledge philosophically, divides it into many so-called sciences and the mature student aspiring to do research work and make some contribution to our fund of knowledge necessarily confines his study to some small portion of a single science. Moreover, he can hope to succeed only by acquiring the technique of the specialist.

The great mass of humanity, however-those engaged in the world's work, laboring in the humbler walks of life, in production, as in agriculture, horticulture, gardening, stock raising or in min- 
ing, or in the manufacturing industries, or in trade and commerce, or even in many of the professions - these people have slight need of such special training and technique. They need, instead, an insight into the broad general principles of science, and above all they need to see clearly and to comprehend the significance of science as it spins and weaves the social fabric of modern civilization.

\section{Science Must Be. Disseminated.}

To neglect the training of research workers in the field of science would be fatal to further progress in man's control of $\mathrm{Na}$ ture and her forces. It would mean stagnation in material progress and that must ever mean stagnation in mental, moral and spiritual progress. But, on the other hand, to neglect the interpretation and dissemination of scientific knowledge and the training of the masses of common people in scientific thinking is to rob humanity, in a large measure, of the fruits of scientific research. It is to the interest of all humanity that even the humblest laborer, toiling with pick and shovel, shall have some knowledge of the laws of science as related to his labor and his living. Modern civilization and all that is most significant to the common people in the way of improved living conditions, of more efficient labor, of shorter hours of labor and of greater facilities for recreation and pleasure depend largely and primarily tpon, first, the achievements of the research worker in revealing the truths of science, and second, upon the dissemination of those truths among the common people and the training of the masses in thinking scientifically.

We are confronted today with no danger of neglecting the training of research workers in the field of science. Every great university in the land is chiefly engaged in this work. The ablest men in their science departments are spending their energies in training research workers in their graduate departments. The undergraduate departments of these universities, and most of our colleges, are largely engaged in preparing students to enter these graduate schools while the science courses in our high schools are in the main shaped and determined by college entrance requirements. Our high schools are vestibules to the college; our colleges are vestibules to the graduate school of the university. From top to bottom and from bottom to top the science work in our educational institutions is chiefly shaped and planned to furnish a direct path for the training of research workers. It is necessary that such a path be provided. But, 
we must not lose sight of the fact that it is equally necessary that the needs of the masses of young people, preparing not for research work but for the ordinary activities of life, receive some consideration. Science falls far short of fulfilling its mission unless the fruits of scientific research fall upon fertile soil and take root in the daily life-activities of the masses.

Are our educational institutions preparing the masses to appreciate and utilize the products of research work in science? This can be done directly and efficiently only through science instruction in our public schools where the masses of young people should learn to interpret and to understand the significance of science as it affects their life work-to think scientifically as they work. And where are our great educational institutions which stand out conspicuously for their efforts and accomplishments in the training of science teachers for our public schools? Where are our great universities which emphasize the art of interpreting and disseminating the fruits of scientific research as they emphasize the art of research itself?

\section{Decline of Science.}

Notwithstanding the increased importance of science as a factor in modern life, it is a fact well known to students of education that the percentage of students studying the older sciences in cur public schools is on the decline, and has been on the decline for twenty years. Leading educators have from time to time called attention to this fact. The Commissioner of Education has repeatedly shown it in his reports. And yet, the rank and file of public school superintendents, principals, and science teachers have until recently sat idly by, alternately boasting of the triumphs of science and lamenting the slowness of the farmer, of the laboring classes, in fact, of the masses everywhere, to avail themselves of the fruits of scientific research in their daily life-activities.

In commenting upon the tendencies in our high schools the Commissioner of Education in his report, 1911, reviewing the educational progress of the decade, says, "Latin is holding its ground; French and German are gaining; algebra occupies a large share of time and is steady; geometry is gaining; English and history have gained materially; all the older sciences, rather strangely, are relatively falling off."

At last we are waking up to the situation. We are beginning to realize that something is wrong-radically wrong-with our public school work in science. What is the trouble? Have you diagnosed the malady? Have you a remedy to suggest? 


\section{Over Specialization.}

Some of us are convinced that the malady with which the public school science is suffering is directly traceable to an overdose of specialization. The needs of the research specialist are dominating and determining largely the college courses in science;

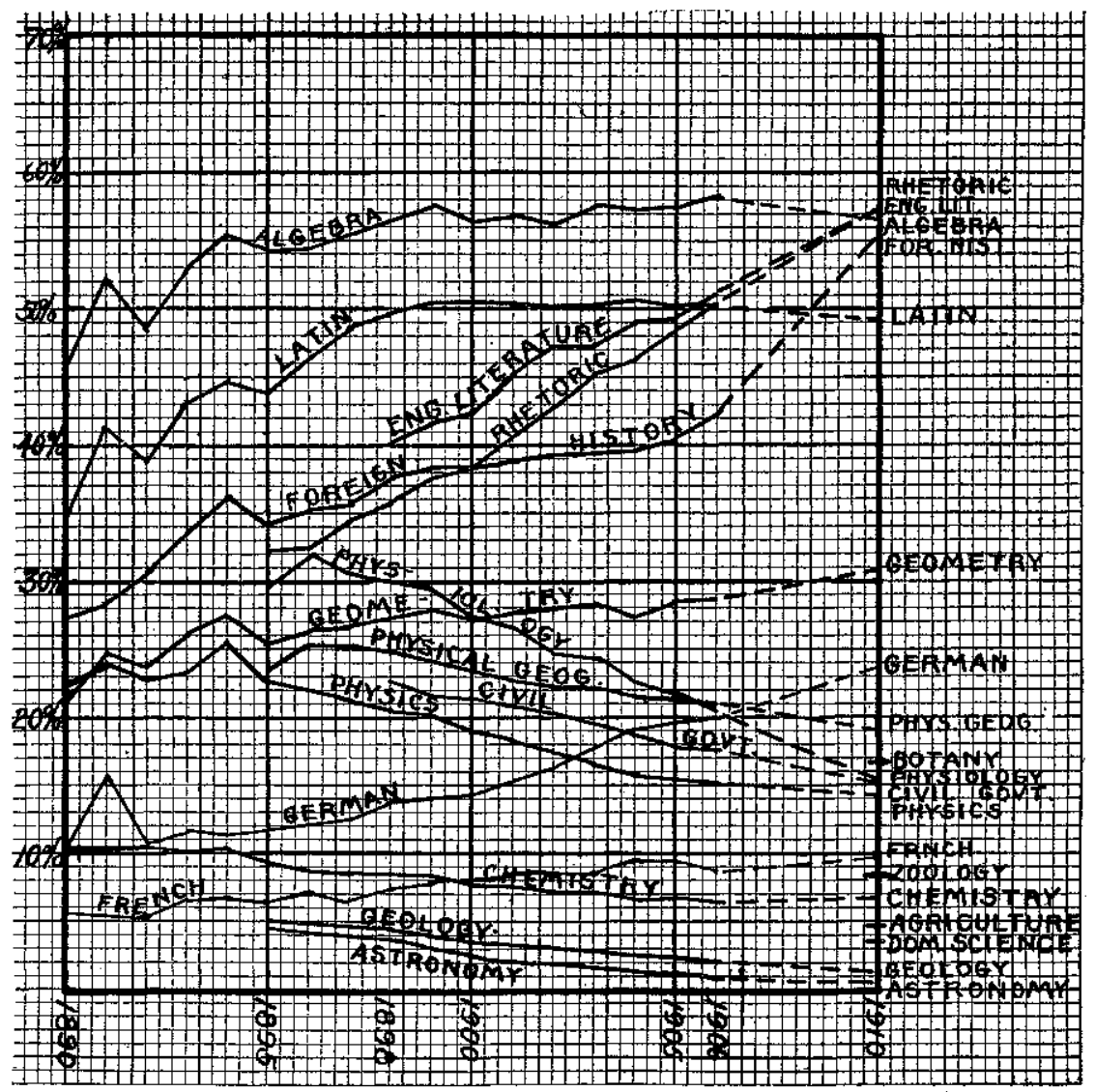

Graph, showing percentage of students studying each of the subjects in the public high schools of the United States during the twenty years from 1890 to 1910. From the report of the Commissioner of. Education, 1910. Vol. 2, p. 1139.

college entrance requirements almost completely determine the character of our high school courses in science. We have built our science courses from the top downwards. We have attempted to start every fourteen-year-old boy and girl entering the high 
school upon the path laid out for the benefit of the exceptional boy or girl who may become a research worker in the university. We have presumed that every fourteen-year-old youth is eager and ready to think in abstract terms. We have attempted to feed him on abstract principles and generalizations, never pausing to inquire about his likes and dislikes or to study the fundamental characteristics of the adolescent mind. We have failed to note that boys and girls of fourteen are chiefly interested in learnings things for the sake of knowing those particular things. The adolescent is not yet a philosopher. Abstractions, generalizations and typestudies are foreign and distasteful to the normal adolescent mind. Youth is ambitious, but it ever seeks the short cut. Necessity also plants its iron heel firmly down upon the ambition of the youth from the toiling classes. The wail and clamor from hungry mouths, the pleadings for the necessities of life are ever ringing in his ear, and in the ear of his parents. If he enters the high school at all it is generally for the purpose of spending one or two years, possibly three or four years, in better preparing himself for life's work-for the struggle of earning a living. The boys and girls from the laboring classes, indeed, from the masses of the common people everywhere, as well as their parents, have a right to demand that they be shown the worth-whileness of the tasks set before them. Can our high school principals and science teachers do this successfully while following the usual courses in special science shaped and planned for a different purpose?

The disregard of the nature and character of the adolescent mind together with the failure of the high school to offer subject matter which appeals to the boys and girls from the masses as being worth while largely accounts for the fact that only about 30 per cent of the boys and girls of high school age ever enter the high school and that 40 per cent of those who do enter quit the first year and only 28 per cent of them complete the course and graduate. Educators are beginning to realize these facts. The widespread conviction that our science courses in the high school mist be revised is one of the results of this awakening. The experiment of putting so-called general science in the first high school year is part of this movement.

\section{Present Status of General Science.}

At the request of the chairman of the Science Section of the National Educational Association, I undertook last summer to discover the status of what is known as general science. I endeavored to ascertain where and in how many high schools courses 
called general science were being taught and later to obtain from the principals of some of those schools information as to what they were attempting to do and with what measure of success their efforts were meeting. From my investigation I conclude that during the school year of 1913-14 not less than 250 or 300 schools in the United States attacked the problem of revising their science courses by offering a course which they called general science while large numbers of other schools seriously contemplated doing so soon.

About June 1, 1914, a questionnaire was sent to 180 schools reported as offering a course in general science. With few exceptions these were addressed to the principals. Up to June 25, replies from 73 . schools had been received. No course called general science was reported from six schools. Replies from 67 schools indicate that they had seriously atteripted work in general science as they understood the term. All the questions were framed with the idea of stimulating thought rather than obtaining ease of tabulation. Some of the replies were consequently rather difficult to tabulate, but it is the belief of the writer that a truer expression of ideas was obtained.

A complete analysis of this report is unnecessary. Facts, if correctly reported, are facts, and therefore undebatable. They are, nevertheless, of the greatest value since they furnish the only reliable basis for opinion. I shall call attention to but two items under the questions of fact. First, in replying to the second question, Length of course offered, but one school reports a course in general science more than one year in length. I predict with confidence that a similar investigation ten years hence, possibly five years hence, will reveal many schools offering such courses two years in length. Second, in reply to the question what text was used, eleven different texts were used in giving general science courses. To one at all familiar with the science texts available during the school year of 1913-14 the replies to this question together with the answers to the tenth question in the second list, indicate that up to that date at least no generally satisfactory texts had made their appearance. I am also convinced that for some years to come, at least until there is available a stupply of teachers especially trained to teach general science, textbooks presenting well organized courses will be as necessary in general science as they are in special science or in any other subject offered in our high schools. The greatest need today, one felt keenly by every science teacher who has become convinced that our science teach- 
ing has become too highly specialized, is for organized courses in general science. Furthermore, however true it may be that the best science teaching in the first high school year is merely the teaching of the science of the pupil's environment, it is asking the impossible when we ask each teacher to organize such material and put it in teachable and available form.

Passing to the questions of opinion: Opinions are always debatable but the answers to the first and second questions:

1. In your judgment, has the work in general science been a success? Answers: Yes, 47; Decidedly so, 13; Doubtful, 4; No, 1; Don't know, 2.

2. Has its degree of success been greater or less than might have been obtained from systematic, special science in the same grade taught by the same teacher? Answers: Yes, 49; Doubtful, 7; Don't know, 1; Not the question, 1; Anwer later, 2.

indicate clearly, to my mind, that thus far the experiments with so-called general science have met the approval of the principals of the schools in which they have been tried. It was most interesting to me to discover that the only person answering the first question in the negative answered the second question in the affirmative.

In my judgment the most significant question in the entire set was the sixth in the second list: Should the units of instruction in general science differ materially from those in special science? And yet, there were fewer answers to this question than to any other. The term, "units of instruction" seems not to have been understood and still from the replies one is warranted in concluding that many of the respondents have no clearly formulated ideas regarding the real nature and real significance of the general science movement. Science organized and developed into units of instruction not materially differing from the units of instruction in special science can be nothing other than special science. To attempt to organize science material without recognizing the fundamental difference in the organization of special science and general science is certain to result, it seems to me, in a mere collection of loosely related principles picked from the various special sciences. Those principles may be the most interesting and striking principles of the special sciences and yet such a course might easily have considerably less significance as educative material than any course in special science. Apparently much of the so-called general science thus far taught is simply fragmentary special science and of very doubtful educational value.

( $T o$ be finished in April.) 